\title{
Electro-generation of hydrogen peroxide using a graphite cathode from exhausted batteries: Study of influential parameters on electro-Fenton process
}

Ibrahima Diouf, Oumar Dia, Moussa Bagha Diedhiou, Patrick Drogui, Alpha Ousmane Toure, Sidy Mambaye Lo, Michel Rumeau \& Codou Gueye Mar/ Diop

To cite this article: Ibrahima Diouf, Oumar Dia, Moussa Bagha Diedhiou, Patrick Drogui, Alpha Ousmane Toure, Sidy Mambaye Lo, Michel Rumeau \& Codou Gueye Mar/Diop (2018): Electro-generation of hydrogen peroxide using a graphite cathode from exhausted batteries: Study of influential parameters on electro-Fenton process, Environmental Technology, DOI: 10.1080/09593330.2018.1537309

To link to this article: https://doi.org/10.1080/09593330.2018.1537309

Accepted author version posted online: 16 Oct 2018.

Submit your article to this journal $₫$

View Crossmark data $\nearrow$ 
Publisher: Taylor \& Francis \& Informa UK Limited, trading as Taylor \& Francis Group

Journal: Environmental Technology

DOI: $10.1080 / 09593330.2018 .1537309$

Electro-generation of hydrogen peroxide using a graphite cathode from exhausted batteries: Study of influential parameters on electro-Fenton process

Ibrahima DIOUF ${ }^{1}$, Oumar DIA ${ }^{2}$, Moussa Bagha DIEDHIOU ${ }^{1}$, Patrick DROGUI ${ }^{2 *}$, Alpha Ousmane TOURE ${ }^{1}$ Sidy Mambaye LO ${ }^{1}$, Michel RUMEAU ${ }^{1}$, Codou GUEYE MAR/DIOP ${ }^{1}$

1 Laboratoire d'Electrochimie et des Procédés Membranaires, Ecole Supérieure Polytechnique, Université Cheikh Anta Diop, B.P : 5085, Dakar-Fann, Senegal.

2 Institut national de la recherche scientifique (INRS-Eau Terre et Environnement), Université du Quebec, 490 rue de la Couronne, Quebec QC G1K 9A9, Canada

*Corresponding author: Patrick DROGUI patrick.drogui@inrs.ca

Ibrahima DIOUFibaradiouf@yahoo.fr

Oumar DIA Oumar.Dia@ete.inrs.ca

Patrick DROGUI patrick.drogui@inrs.ca

Sidy Mambaye LO sidymambaye.fara@gmail.com

Alpha Ousmane TOURE alpha2re@gmail.com

Michel RUMEAU mj.rumeau@gmail.com

Moussa Bagha DIEDHIOU diebagha@yahoo.fr 


\title{
Codou GUEYE MAR/DIOP cgmare@gmail.com
}

\begin{abstract}
In this work, the study of hydrogen peroxide $\left(\mathrm{H}_{2} \mathrm{O}_{2}\right)$ electro-generation using graphite from exhausted batteries (Gr-Bat) was conducted. Linear sweep voltammetry and electrolysis experiments were carried out in a single compartment electrochemical cell. Study of the possibility to use this electrode revealed that it presents, as vitreous carbon (VC) electrode, a reduction of oxygen with two successive waves (bi-electronic reduction). The first wave corresponds to the reduction of $\mathrm{O}_{2}$ to $\mathrm{H}_{2} \mathrm{O}_{2}$, while the second one corresponds to the reduction of $\mathrm{H}_{2} \mathrm{O}_{2}$ to $\mathrm{H}_{2} \mathrm{O}$. The cathodic potentials for electro-generation of $\mathrm{H}_{2} \mathrm{O}_{2}$ appeared at $-600 \mathrm{mV}$ and $-700 \mathrm{mV} V s \mathrm{Ag} / \mathrm{AgCl}$ for $\mathrm{Gr}-\mathrm{Bat}$ and $\mathrm{VC}$ electrodes, respectively. Subsequently, electrolysis experiments were conducted by imposing the potentials required for $\mathrm{H}_{2} \mathrm{O}_{2}$ formation. The effect of several operating parameters on $\mathrm{H}_{2} \mathrm{O}_{2}$ production, such as the nature and concentration of the electrolyte, the $\mathrm{pH}$, the presence of ferrous ions and $\mathrm{O}_{2}$ injection were studied using Gr-Bat and VC electrodes, respectively. For both electrodes, the acidic medium was more favorable for $\mathrm{H}_{2} \mathrm{O}_{2}$ electro-generation. The oxygen injection in solution promoted an increase of $\mathrm{H}_{2} \mathrm{O}_{2}$ concentration, but its effect was more pronounced in the case of VC electrode. Application for crystal violet degradation by electro-Fenton revealed that GrBat had the best purification performance. A removal rate of $73.18 \%$ was obtained with $\mathrm{Gr}$ Bat electrode against $62.27 \%$ with VC electrode for an electrolysis time of $120 \mathrm{~min}$. This study has demonstrated the possibility of recycling Gr-Bat by using them as cathode materials in the electro-Fenton process.
\end{abstract}

Keywords: Exhausted batteries, Hydrogen peroxide, Electro-Fenton, Electro-reduction of $\mathrm{O}_{2}$, Crystal violet

\section{Introduction}

Many treatment methods had been developed in order to tackle the issue of aquatic environment degradation by refractory organic pollutants. Among these innovations, Advanced Oxidation Processes (AOPs) play an important role [1, 2]. AOPs are new treatment 
technologies that can be used to effectively remove pollutants from surface waters and refractory micro-pollutants found in many influents $[3,4]$.

AOPs are based on in situ generation of radical hydroxyls that are very powerful and nonselective oxidants capable to degrade organic compounds present in influents [5]. Hydroxyl radicals $\left(\mathrm{OH}^{\bullet}\right)$, the most powerful oxidants used in water and wastewater treatment, have a high potential $\left(\mathrm{E}^{\circ}{ }_{\mathrm{OH}}{ }^{\bullet} / \mathrm{H}_{2} \mathrm{O}=2.8 \mathrm{~V} / \mathrm{ENH}\right)$ and they enable to oxidize organic compounds until their last stage of mineralization to $\mathrm{CO}_{2}, \mathrm{H}_{2} \mathrm{O}$ and other inorganic ions $[6,7]$. $\mathrm{OH}^{\bullet}$ can be generated via a process called electro-Fenton (EF). It is an electrochemical process that has received a considerable attention in recent years $[8,9,10]$. Its principle is based on the use of Fenton reagent (hydrogen peroxide $\mathrm{H}_{2} \mathrm{O}_{2}$ and ferrous ions $\mathrm{Fe}^{2+}$ ) in order to generate hydroxyl radical as shown in the following reaction (Eq. 1):

$$
\mathrm{H}_{2} \mathrm{O}_{2}+\mathrm{Fe}^{2+} \rightarrow \mathrm{Fe}^{3+}+\mathrm{OH}^{-}+\mathrm{OH}^{\cdot}
$$

The main advantage of this process is the in situ electro-generation of hydrogen peroxide using only dissolved oxygen as reagent [11]. A cathodic reduction will then occur on the appropriate electrodes such us carbon felt, graphite, reticulated vitreous carbon, activated carbon fiber, carbon nanotube $[12,13,14,15]$ as mention in the following reactions (Eq. 2 and 3 ).

In acidic medium

$$
\mathrm{O}_{2}+2 \mathrm{H}^{+}+2 \mathrm{e}^{-} \rightarrow \mathrm{H}_{2} \mathrm{O}_{2}
$$

In alkaline medium

$$
\mathrm{O}_{2}+\mathrm{H}_{2} \mathrm{O}+2 \mathrm{e}^{-} \rightarrow \mathrm{HO}_{2}^{-}+\mathrm{OH}^{-}
$$

The ferric ions $\left(\mathrm{Fe}^{3+}\right)$, cogenerated from the hydroxyl radical formation (Eq. 1), are electrochemically reduced back at the cathode to ferrous ions $\left(\mathrm{Fe}^{2+}\right)(\mathrm{Eq} .4)$. In this way, the iron is recycled in the redox cycle and the amount of iron hydroxide sludge is considerably reduced [16].

$$
\mathrm{Fe}^{3+}+\mathrm{e}^{-} \rightarrow \mathrm{Fe}^{2+}
$$

The main advantages of this process are the possibility to continuously generate $\mathrm{H}_{2} \mathrm{O}_{2}$ and $\mathrm{Fe}^{2+}$ in the reactor that reduced risks and costs associated with transportation, acquisition, storage, production and disposal of hazardous waste [17, 18, 19]. Therefore, EF process is an interesting alternative for the treatment of effluents containing high refractory organic compounds [20]. However, it is worth mentioning that this process is hindered by some 
drawbacks such as the production of hydrogen peroxide which is controlled by the electroreduction of dissolved oxygen.

The dissolved $\mathrm{O}_{2}$ electro-reduction reaction is highly depended to the cathodic material [21]. Thus a judicious choice of the cathode material is required during the implementation of this method. The selected cathode should present two waves of oxygen reduction and have high hydrogen overpotential. In addition to be non-toxic and have a good chemical resistance, the cathodic material should also have less interaction with the generated $\mathrm{H}_{2} \mathrm{O}_{2}$ in order to facilitate its diffusion in the solution and avoid its eventual self-destruction on the cathode [17]. A good electrical conductivity and an affordable cost are to be taken account for the cathodic material choice $[22,23]$.

In order to find a way to recycle waste from the batteries industry, we tried, in this study, to investigate the capacity of carbon rods (graphite), from exhausted batteries, to produce $\mathrm{H}_{2} \mathrm{O}_{2}$ by $\mathrm{O}_{2}$ reduction. Furthermore, the possible use of this material was tested as an alternative cathode in the EF process. The effect of some influential parameters such as the cell voltage, the solution $\mathrm{pH}$, the electrolyte concentration, and the $\mathrm{O}_{2}$ bubbling on $\mathrm{H}_{2} \mathrm{O}_{2}$ production was investigated. Later on, this approach was used to evaluate the degradation of crystal violet pollutant in synthetic solution.

\section{Material et methods}

\subsection{Electrochemical cell and analytical methods}

Experiments were conducted in a $250 \mathrm{~mL}$ non compartmental cell. The anode was made of Ti $/ \mathrm{RuO}_{2}-\mathrm{IrO}_{2}$ electrode with a surface area of $7.15 \mathrm{~cm}^{2}$. The two cathodes used in this study were graphite carbon from exhausted batteries (Gr-Bat) provided by the company SIGELECSenegal, and vitreous carbon (VC) having both a surface area of $9.5 \mathrm{~cm}^{2}$.

The two chosen electrodes (anode and cathode) were immersed in the aqueous solution with a third $\mathrm{Ag} / \mathrm{AgCl}$ reference electrode and the reactor was kept under magnetic stirring in order to improve oxygen mass transfer to the surface of the cathode. The electrodes were connected to a potentiometer Radiometer Analytical Voltalab PGZ-100 ALL IN ONE controlled by the Master 4 software. The crystal violet concentration was determined using a UV-visible spectrophotometer Analytik Jena model SPECORD 200 PLUS with a wavelength set at 592 $\mathrm{nm}$. The $\mathrm{pH}$ was measured by a $\mathrm{pH}$ meter HANNA Instruments HI223 and the conductivity was measured by EC 214 Conductivity meter HANNA Instruments. 
In order to estimate the concentration of electro-generated $\mathrm{H}_{2} \mathrm{O}_{2}$ over the time, the system was stopped and a sample was taken and analyzed using a manganimetry based method [24]. It is a titrimetric determination of $\mathrm{H}_{2} \mathrm{O}_{2}$ based on the reduction of $\mathrm{MnO}_{4}{ }^{-}$ions to $\mathrm{Mn}^{2+}$ under acidic medium according to the following reaction (Eq. 5):

$$
2 \mathrm{MnO}_{4}^{-}+5 \mathrm{H}_{2} \mathrm{O}_{2}+6 \mathrm{H}^{+} \rightarrow \mathrm{Mn}^{2+}+5 \mathrm{O}_{2}+8 \mathrm{H}_{2} \mathrm{O}
$$

The concentration of $\mathrm{H}_{2} \mathrm{O}_{2}$ was expressed by the following relation (Equation 6):

$$
\left[\mathrm{H}_{2} \mathrm{O}_{2}\right]\left(\mathrm{g} . \mathrm{L}^{-1}\right)=\frac{5}{2} \times \frac{\mathrm{N}_{\mathrm{KMnO}_{4}} \times \mathrm{V}_{\mathrm{KMnO}_{4}}}{\mathrm{~V}_{\mathrm{H}_{2} \mathrm{O}_{2}}} \times 34 \times 10^{-3}
$$

Where $\mathrm{N}_{\mathrm{KMnO} 4}$ is the molar concentration of the potassium permanganate solution (mol L $\mathrm{L}^{-1}$ ) and $\mathrm{V}_{\mathrm{KMnO}}$ and $\mathrm{V}_{\mathrm{H}_{2} \mathrm{O}_{2}}$ are the volumes of potassium permanganate solution and the sample respectively.

\subsection{Reduction of dissolved oxygen on graphite and carbon vitreous electrodes}

The objectives of this part were as following: 1) to verify whether the carbon-graphite electrode from exhausted batteries (Gr-Bat) had two waves $\mathrm{O}_{2}$ reduction kinetic allowing a production of $\mathrm{H}_{2} \mathrm{O}_{2} ; 2$ ) to determine the electrochemical potential region for $\mathrm{O}_{2}$ reduction to $\mathrm{H}_{2} \mathrm{O}_{2}$; 3) to evaluate the impact of the use of $\mathrm{NaCl}$ as electrolyte on the production of hydrogen peroxide. To do this, firstly, a comparison had been made between Gr-Bat cathodic polarization curves and curves obtained with carbon vitreous described in the literature as a cathode showing two waves oxygen reduction kinetic [19]. Secondly, we compared the cathodic polarization curves of $\mathrm{O}_{2}$ reduction using Gr-Bat cathode obtained with $\mathrm{NaCl}$ as supporting electrolyte and those recorded with $\mathrm{Na}_{2} \mathrm{SO}_{4}$ generally used in the electro-Fenton process as supporting electrolyte [13].

\subsection{Chemicals}

All the reagents used in this work were analytical grade. Sulfuric acid $\left(\mathrm{H}_{2} \mathrm{SO}_{4}\right)$, sodium chloride $(\mathrm{NaCl})$, and crystal violet $\left(\mathrm{C}_{25} \mathrm{H}_{30} \mathrm{ClN}_{3}\right)$ were purchased from Sigma Aldrich. Potassium permanganate $\left(\mathrm{KMnO}_{4}\right)$ and sodium sulfate $\left(\mathrm{Na}_{2} \mathrm{SO}_{4}\right)$ were purchased from Scharlau Company while iron sulfate $\left(\mathrm{FeSO}_{4}\right)$ from Merck and sodium hydroxide $(\mathrm{NaOH})$ from Fisher Scientific. A $14 \mathrm{~m}^{3}$ nitrogen bottle $\left(\mathrm{N}_{2}\right)$ supplied by AIR-LIQUIDE- Senegal company and a $7 \mathrm{~m}^{3}$ oxygen cylinder $\left(\mathrm{O}_{2}\right)$ supplied by EUROSAF OXYGEN were used in the experiments. Distilled water was also employed throughout the aqueous solutions preparation. 


\section{Results and discussion}

\subsection{Study of the electrochemical region of $\mathrm{H}_{2} \mathrm{O}_{2}$ production and effect of influential parameters}

\subsubsection{Comparative study of $\mathrm{O}_{2}$ reduction kinetics}

The kinetic study of oxygen reduction on both electrodes (VC and Gr-Bat) was conducted using a linear sweep voltammetry under the different following conditions: a) $3 \mathrm{~g}^{-1}$ of $\mathrm{Na}_{2} \mathrm{SO}_{4}$; b) $3 \mathrm{~g} \mathrm{~L}^{-1}$ of $\mathrm{Na}_{2} \mathrm{SO}_{4}+\mathrm{O}_{2}$ bubbling; c) $3 \mathrm{~g} \mathrm{~L}^{-1}$ of $\mathrm{Na}_{2} \mathrm{SO}_{4}+\mathrm{N}_{2}$ bubbling. The potential varied from 0 to $-2500 \mathrm{mV} V s \mathrm{Ag} / \mathrm{AgCl}$ reference electrode with a scan rate of 10 $\mathrm{mV} \mathrm{s}^{-1}$.

The results obtained from linear voltammetry study on VC and Gr-Bat electrodes are recorded in Figures 1A and 1B, respectively.

\section{Figure $1(A$ and $B)$}

The results revealed that, like VC electrode, the Gr-Bat electrode shown two waves oxygen reduction kinetic. Thereby, it can be used for $\mathrm{H}_{2} \mathrm{O}_{2}$ electro-generation. The first wave, corresponding to the reduction of $\mathrm{O}_{2}$ to $\mathrm{H}_{2} \mathrm{O}_{2}$, was obtained between -684 and $-920 \mathrm{mV}$ for VC electrode and between -522 and $-850 \mathrm{mV}$ for Gr-Bat electrode. This shows that the GrBat electrode have the lowest $\mathrm{O}_{2}$ reduction potential. In both cases the oxygen bubbling did not change significantly the shape of the curves; a two steps reduction was always observed. However, it has the effect of increasing the value of the diffusion limit currents. For example, in the case of Gr-Bat electrode, at a potential of $-1000 \mathrm{mV}$, the $\mathrm{O}_{2}$ sparging increased the current limit from $-2.04 \times 10^{-3}$ to $-3.32 \times 10^{-3} \mathrm{~mA}$ and lowered the hydrogen overvoltage value. $\mathrm{N}_{2}$ bubbling removed the dissolved oxygen in the solution. In both cases, the disappearance of the first wave with the nitrogen sparging confirmed that the first step was due to the reduction of oxygen to hydrogen peroxide.

Results from Figures $1 \mathrm{~A}$ and $1 \mathrm{~B}$ revealed also that the Gr-Bat electrode has the highest hydrogen overvoltage with $-1836 \mathrm{mV}$ against $-1770 \mathrm{mV}$ for vitreous carbon and the latter had limited diffusion currents sometimes ten times higher than those for Gr-Bat electrode. Indeed, at a potential of $-2000 \mathrm{mV}$, the diffusion limited currents without $\mathrm{O}_{2}$ sparging were $-7.41 .10^{-2}$ 
and $-6.36 .10^{-3} \mathrm{~mA}$ for the VC and Gr-Bat electrodes respectively. This can be attributed to the intrinsic characteristics of these two materials such as their texture and difference in electrical conductivity.

\subsubsection{Influence of type and concentration of electrolyte}

The effect of type and concentration of the electrolyte on $\mathrm{O}_{2}$ reduction had been studied using different $\mathrm{NaCl}$ and $\mathrm{Na}_{2} \mathrm{SO}_{4}$ concentrations. The use of $\mathrm{NaCl}$ in electrochemical treatment processes such as electro-oxidation and electro-Fenton leads to very interesting results [25]. It allows an in situ generation of other oxidizing agents such as hypochlorite ion $\mathrm{ClO}^{-}$and hypochlorous acid $\mathrm{HClO}$ via the following reactions (Eqs. 7, 8 and 9):

$$
\begin{gathered}
2 \mathrm{Cl}^{-} \rightarrow \mathrm{Cl}_{2}+2 \mathrm{e}^{-} \\
\mathrm{Cl}_{2}+\mathrm{H}_{2} \mathrm{O} \rightarrow \mathrm{HClO}+\mathrm{H}^{+}+\mathrm{Cl}^{-} \\
\mathrm{HClO} \rightarrow \mathrm{ClO}^{-}+\mathrm{H}^{+}
\end{gathered}
$$

Hence, these electro-generated oxidants can contribute to the degradation of the dissolved organic pollutants. Therefore, the use of such electrolytes improves the efficacy of the treatment [26]. Results obtained using $\mathrm{NaCl}$ are shown in Figure 2A. The cathodic scanning was carried out from 0 to $-2500 \mathrm{mV}$ with a scan rate of $10 \mathrm{mV} \mathrm{s}^{-1}$.

Figure 2 (A and B)

These results show that similarly to $\mathrm{Na}_{2} \mathrm{SO}_{4}, \mathrm{NaCl}$ can be used as an electrolyte in the production of hydrogen peroxide. The polarization curves show that the two waves of $\mathrm{O}_{2}$ reduction were always present, reflecting the formation of hydrogen peroxide. By comparing the curves of Figure $2 \mathrm{~A}$ with those obtained in Figure 1B using $\mathrm{Na}_{2} \mathrm{SO}_{4}$ as electrolyte, it can be seen that the use of $\mathrm{NaCl}$ had an effect on the oxygen reduction potential. Indeed, a diminution of this potential was observed with the use of $\mathrm{NaCl}$. Depending on the electrolyte type, the value of the current limits varied due to the difference in conductivity of the two supporting electrolytes, $\mathrm{Na}_{2} \mathrm{SO}_{4}(3.52 \mathrm{mS})$ and $\mathrm{NaCl}(4.77 \mathrm{mS})$. 
Moreover, study of the effect of electrolyte concentration was carried out using $\mathrm{Na}_{2} \mathrm{SO}_{4}$ at the same scan rate as above with continuous $\mathrm{O}_{2}$ sparging. Results, plotted in Figure 2B, revealed that the increase of electrolyte concentration did not change the curves shape. The reduction of $\mathrm{O}_{2}$ at two levels was always observed but the diffusion limited currents increased with the electrolyte concentration. This was expected because the electrolyte role consists to reduce the electrical resistance by facilitating the passage of the current in the solution. Hence, the limited currents increased when the solution was more and more concentrated in electrolyte. However, it should also be noted that the potentials reduction became lower and lower as the solution became more and more concentrated in electrolyte.

\subsubsection{Influence of $\mathbf{p H}$}

The effect of $\mathrm{pH}$ on oxygen reduction was studied using $\mathrm{Na}_{2} \mathrm{SO}_{4}$ as electrolyte; the concentration was fixed at $3 \mathrm{~g} \mathrm{~L}^{-1}$. This study was conducted in order to determine in which regional of $\mathrm{pH}$ the hydrogen peroxide generation was optimal. It was carried out on solutions having $\mathrm{pH}$ of 3, 5.4 (initial $\mathrm{pH}), 7$, and 10 with continuous $\mathrm{O}_{2}$ sparging. Sulfuric acid $\left(\mathrm{H}_{2} \mathrm{SO}_{4}\right)$ was used to acidify the medium to $\mathrm{pH} 3$ while sodium hydroxide $(\mathrm{NaOH})$ was used to raise the $\mathrm{pH}$ to 7 and 10 . The obtained results are shown in Figure $3 \mathrm{~A}$.

\section{Figure 3A}

These results revealed that the diffusion limited currents were higher in acidic medium (initial solution and $\mathrm{pH} 3$ ) showing the quantity of dissolved oxygen participating in the reaction was more important and leading to higher $\mathrm{H}_{2} \mathrm{O}_{2}$ production. The increase of diffusion limited currents in acidic solutions can be attributed either to oxygen which is much more soluble in acid medium [20] or to the high concentration of $\mathrm{H}^{+}$protons in acid medium.

Indeed, as shown by the Equation 2, the hydrogen peroxide is generated from $\mathrm{H}^{+}$protons and dissolved $\mathrm{O}_{2}$ in the solution, and these two species are more available in solution when the $\mathrm{pH}$ medium is acidic. However, the increase of the amount of hydrogen peroxide can also be attributed to the intrinsic properties of the material [20] such as its adsorption ability of 
dissolved oxygen and desorption of hydrogen peroxide generated from its surface to the solution or to the synergism effects of these phenomena.

These findings are interesting for an eventual use of this electrode in the electro-Fenton process. Indeed, several recent studies have shown that this process is more efficient when the $\mathrm{pH}$ is around $3[1,10,13]$. In addition, results revealed that hydrogen overvoltage is much lower in acidic solutions. Qiang et al [17] explained this by the high concentration of $\mathrm{H}^{+}$ protons that facilitates the hydrogen evolution reaction and thus reduce the efficiency of hydrogen peroxide formation.

\subsubsection{Effect of ferrous ions concentration}

In order to have an idea about the behavior of these electrodes during their use in the electroFenton process, the effect of ferrous ions concentration on $\mathrm{O}_{2}$ reduction reaction had been investigated. In the electro-Fenton process, these ions are used to generate hydroxyl radicals $\mathrm{OH}^{\bullet}$ from hydrogen peroxide according to Equation 1 called the Fenton reaction. However, the concentration of ferrous ions should be optimized. Several studies have shown that it greatly influences the electro-Fenton process [16, 22]. The study of the effect of iron sulfate concentration was conducted using $3 \mathrm{gL}^{-1}$ of $\mathrm{Na}_{2} \mathrm{SO}_{4}$ with $\mathrm{O}_{2}$ sparging and a scan rate of 10 $\mathrm{mV} / \mathrm{s}$ at room temperature.

\section{Figure 3B}

The results presented in Figure 3B show that the presence of iron sulfate in the solution affected the reduction of oxygen. In all experiments, the presence of iron sulfate caused an increase of the limit of the diffusion current in comparison to the initial solution, but the shape of the reduction curves did not change. This can be explained by the increase of conductivity with the presence of $\mathrm{Fe}^{2+}$ and $\mathrm{SO}_{4}{ }^{2-}$ ions [27]. In addition, the presence of ferrous and sulfate ions reduced both the hydrogen overvoltage and the potential corresponding to oxygen peroxide reduction in comparison to the control solution. This was also observed in the case of increase in electrolyte concentration, it can be explained by the decrease of the cell resistance when the solution is more and more conductive. 
There was an increase of the limit of the diffusion current when the iron concentration varied from 0 to $7.2 \times 10^{-3} \mathrm{M}$. However, when the iron concentration increases (from $7.2 \times 10^{-3}$ to $\left.10.8 \times 10^{-3} \mathrm{M}\right)$ a decrease of the limit of the diffusion current was recorded.

\subsection{Study of the effect of the operating parameters on the quantity of electro-generated} $\mathrm{H}_{2} \mathrm{O}_{2}$

\subsubsection{Effect of applied voltage}

The comparative study of the voltage influence on $\mathrm{H}_{2} \mathrm{O}_{2}$ electro-generation was carried out in $250 \mathrm{~mL}$ solution containing $3 \mathrm{~g} \mathrm{~L}^{-1}$ of $\mathrm{Na}_{2} \mathrm{SO}_{4}$ during $90 \mathrm{~min}$ of electrolysis time. The results presented in Figure 4A show that the production of $\mathrm{H}_{2} \mathrm{O}_{2}$ was strongly correlated with the voltage applied across the electrodes. In both electrodes, the amount of generated $\mathrm{H}_{2} \mathrm{O}_{2}$ increased with the cathodic potential until an optimal voltage specifie to each electrode. These optimum voltages were $-600 \mathrm{mV}$ for $\mathrm{Gr}$-Bat electrode and $-700 \mathrm{mV}$ for $\mathrm{VC}$ electrode. When the applied voltage was higher than the optimum voltage, the amount of generated $\mathrm{H}_{2} \mathrm{O}_{2}$ decreased immediately resulting in a lower current efficiency in both cases. This observation is attributed to the appearance of undesirable secondary reactions such as $\mathrm{O}_{2}$ reduction to $\mathrm{H}_{2} \mathrm{O}$ and $\mathrm{H}_{2}$ evolution reaction occurring on the cathode surface $[28,20]$.

Figure 4A

These results revealed also that in the investigated potential region, Gr-Bat electrode was more able to generate hydrogen peroxide than $\mathrm{VC}$ electrode. The maximum concentrations of $\mathrm{H}_{2} \mathrm{O}_{2}$ achieved were $5.1 \times 10^{-3} \mathrm{~g} \mathrm{~L}^{-1}$ for Gr-Bat against $4.25 \times 10^{-3} \mathrm{~g} \mathrm{~L}^{-1}$ for $\mathrm{VC}$. The best current efficiency over the entire electrochemical region was obtained with the Gr-Bat electrode. However, it can be noted that the potential region allowing the produce more than $50 \%$ of the maximum value was much wider for vitreous carbon electrode than the graphite electrode.

\subsubsection{Effect of electrolyte concentration}


The electrolyte promotes the passage of the current in the solution by reducing the ohmic resistance and facilitating the electrochemical reactions. Its effect on the electro-generation of hydrogen peroxide was investigated by fixing the cathodic potential at $-600 \mathrm{mV}$ for the $\mathrm{Gr}$ Bat electrode and $-700 \mathrm{mV}$ for the $\mathrm{VC}$ electrode. Different $\mathrm{Na}_{2} \mathrm{SO}_{4}$ concentrations were then experimented ( 1 to $6 \mathrm{~g} \mathrm{~L}^{-1}$ ) during 90 min of electrolysis time.

The results obtained in Figure $4 \mathrm{~B}$ show that the electro-generation of $\mathrm{H}_{2} \mathrm{O}_{2}$ was not significantly affected by the concentration of the supporting electrolyte. Indeed, for both electrodes, a slight variation in the amount of hydrogen peroxide was noted when the electrolyte concentration was increased to its maximum value $\left(6 \times 10^{-3} \mathrm{~g} \mathrm{~L}^{-1}\right)$. These results are consistent with those reported by Azri and Zerouali [29]. These authors shown that, the increase of electrolyte concentration had only an effect on the conductivity of the solution and on migration phenomena of species. Given that the increase of the conductivity via $\mathrm{Na}_{2} \mathrm{SO}_{4}$ addition had no significant effect on $\mathrm{H}_{2} \mathrm{O}_{2}$ production, the concentration of $3 \mathrm{~g} \mathrm{~L}^{-1}$ had been retained for the following experiments.

\section{Figure 4B}

\subsubsection{Effect of the $\mathrm{pH}$}

The $\mathrm{pH}$ is a very important parameter for an electrochemical oxidation processes. Several authors had studied the effect of $\mathrm{pH}$ on electrochemical oxidation of organic matter in aqueous media $[8,20]$. In order to identify in which $\mathrm{pH}$ range the production of hydrogen peroxide was maximum, the effect of this latter was investigated using four different $\mathrm{pH}$ values: 3, initial solution (5.4), 7 and, 10. Sulfuric acid and sodium hydroxide were respectively used to acidify or alkalinize the solution.

Figure 4C 
The results plotted in Figure 4C revealed that the $\mathrm{pH}$ had a significant influence on hydrogen peroxide generation. However, the variation of $\mathrm{H}_{2} \mathrm{O}_{2}$ concentration according to the $\mathrm{pH}$ depends on the type of electrode. The variation was more stressed for the Gr-Bat electrode than VC electrode. For both electrodes, the acidic medium seemed to be more favorable for $\mathrm{H}_{2} \mathrm{O}_{2}$ generation and an optimum $\mathrm{pH}$ of 5.4 for the Gr-Bat and 3 for $\mathrm{VC}$ had been observed. Similar observations had been reported by Petrucci et al [30], Xu et al [20], and of Liu et al [31]. Hsiao and Nobe [32] have studied the degradation of phenol and chlorobenzene using the EF process; they concluded that the current efficiency and the generation of $\mathrm{H}_{2} \mathrm{O}_{2}$ are promoted by the decrease of $\mathrm{pH}$. Xu et al [20] attributed the increase in hydrogen peroxide concentration in acidic medium to the concentration of dissolved oxygen which is higher in acidic medium. These studies have also associated the increase of $\mathrm{H}_{2} \mathrm{O}_{2}$ production in acidic medium with the high availability of $\mathrm{H}^{+}$protons necessary for the production of hydrogen peroxide according to Eq. 2. Nevertheless, it should be pointed out that if the quantity of $\mathrm{H}^{+}$is so important, the hydrogen evolution reaction will be facilitated on the cathode and it will hinder $\mathrm{O}_{2}$ reduction into $\mathrm{H}_{2} \mathrm{O}_{2}$. Other authors have reported that the improvement of $\mathrm{H}_{2} \mathrm{O}_{2}$ electro-generation in acidic medium might be linked to the intrinsic characteristics of the electrode materials, such as their $\mathrm{O}_{2}$ adsorption ability that is improved in acidic medium [33].

\subsubsection{Effect of oxygen sparging}

The study of the impact of $\mathrm{O}_{2}$ sparging on $\mathrm{H}_{2} \mathrm{O}_{2}$ generation was carried out on the two electrodes for three experimental conditions: $3 \mathrm{~g} \mathrm{~L}^{-1}$ of $\mathrm{Na}_{2} \mathrm{SO}_{4}, 3 \mathrm{~g} \mathrm{~L}^{-1}$ of $\mathrm{Na}_{2} \mathrm{SO}_{4}+\mathrm{O}_{2}$ sparging, and $3 \mathrm{~g} \mathrm{~L}^{1}$ of $\mathrm{Na}_{2} \mathrm{SO}_{4}+\mathrm{O}_{2}$ sparging with $\mathrm{pH}$ adjustment at 3. Experiments were performed by maintaining the voltage at -600 and $-700 \mathrm{mV}$ for Gr-Bat and $\mathrm{VC}$ electrodes respectively. The results obtained are shown in Figures 5A and 5B.

\section{Figure $5(A$ and $B)$}

These results indicated that $\mathrm{O}_{2}$ sparging had influence on the production of hydrogen peroxide. Its influence depends on the type of electrode; in fact it is much more pronounced in the case of vitreous carbon electrode where the concentration of peroxide increased from $4.25 \times 10^{-3}$ to $6.38 \times 10^{-3} \mathrm{~g} \mathrm{~L}^{-1}$ for an electrolysis time of $90 \mathrm{~min}$. Under the same operating conditions, only a small evolution of $\mathrm{H}_{2} \mathrm{O}_{2}$ production was observed in the case of the 
graphite electrode. This increase of the amount of $\mathrm{H}_{2} \mathrm{O}_{2}$ was attributed to the increase in dissolved oxygen concentration in solution during the sparging. Indeed, Petrucci et al [30] have shown that the pure oxygen sparging considerably increased the concentration of dissolved oxygen in the solution [34] resulting to the increase in the amount of hydrogen peroxide.

These results show that the VC material presents a better dissolved oxygen adsorption capacity than that Gr-cell. In fact, $\mathrm{O}_{2}$ reduction reaction being a process that takes place on the electrode surface, the more the cathode has the ability to adsorb oxygen the more hydrogen peroxide production will be important. This difference can also be attributed to the electrical conductivity of the two electrodes. Since the oxygen reduction reaction is dependent to the current intensity, the vitreous carbon electrode being more conductiye than Gr-Bat as shown in section 3.1.1., will allow the current to pass more easily. That will accelerate the electrochemical reactions kinetics on its surface and thus increase the quantity of hydrogen peroxide with the oxygen bubbling.

Moreover, these results revealed that the oxygen sparging with $\mathrm{pH}$ adjustment to 3 improved the amount of hydrogen peroxide produced in both cases. This improvement could be explained by the synergistic effect of the three phenomena which are the increase of the solubility of oxygen [33], the high presence of $\mathrm{H}^{+}$protons in acid medium, and the improvement of the materials adsorption capacity at this $\mathrm{pH}$ [33].

\subsection{Application for the degradation of crystal violet by electro-Fenton}

In order to compare the efficiency of the two electrodes, the electrolysis of $7.5 \times 10^{-5} \mathrm{M}$ crystal violet solution was carried out at $\mathrm{pH} 3,5.10^{-2} \mathrm{M}$ of $\mathrm{Na}_{2} \mathrm{SO}_{4}, 10^{-4} \mathrm{M}$ of $\mathrm{Fe}^{2+}$, and a current of intensity of $300 \mathrm{~mA}$. The residual crystal violet concentration was monitored by UV-visible spectroscopy. Electrolysis experiments were performed using a $\mathrm{Ti} / \mathrm{IrO}_{2}-\mathrm{RuO}_{2}$ anode under these three conditions: a) Gr-Bat cathode without $\mathrm{Fe}^{2+}$, b) Gr-Bat cathode $+\mathrm{Fe}^{2+}$, and c) $\mathrm{VC}$ cathode $+\mathrm{Fe}^{2+}$. Figure 6 shows the evolution of crystal violet concentration as a function of the electrolysis time.

\section{Figure 6}


The results revealed that the presence of $\mathrm{Fe}^{2+}$ ions in the solution allows a faster degradation of the crystal violet. This shows that these ferrous ions have allowed the generation of additional oxidizing species in solution proving that these electrodes can be used in the implementation of the electro-Fenton process. In fact, considering an electrolysis time of 120 min with the Gr-Bat electrodes, the addition of the ferrous ions increased the crystal violet degradation rate from 45.75 to $73.18 \%$. In addition, these results also reveal that, under the actual electrolysis conditions, the Gr-Bat electrode remains more effective than VC electrode regarding the removal of crystal violet. For the same electrolysis time (120 min), the crystal violet removal rate was $62.27 \%$ using the $\mathrm{VC}$ electrode. Based on the preyious preliminary study, these results were somehow expected. In fact, the Gr-Bat electrode produced more $\mathrm{H}_{2} \mathrm{O}_{2}$ than $\mathrm{VC}$ electrode. The production of $\mathrm{H}_{2} \mathrm{O}_{2}$ is required for hydroxy radical formation in the presence of ferrous ions during electro-degradation of pollutants (electro-Fenton process).

\section{Conclusion}

The purpose of this study was to find a way to recycle exhausted batteries by using their graphite contain as a cathode material in the electro-Fenton process. Voltammetry studies of dissolved oxygen reduction reaction on this cathode showed that this material has a kinetic of oxygen reduction with two waves revealing the passage through $\mathrm{H}_{2} \mathrm{O}_{2}$ formation. Some operating parameters such as nature and concentration of the electrolyte, $\mathrm{pH}$ and ferrous ion concentration had a significant influence on the diffusion-limited currents and the overvoltage potentials.

Moreover, investigation of the effects of these operating parameters on the amount of hydrogen peroxide revealed that Gr-Bat cathode had the best current efficiency than VC electrode. Hydrogen peroxide concentrations of $5.1 \times 10^{-3}$ and $4.25 \times 10^{-3} \mathrm{~g} \mathrm{~L}^{-1}$ were respectively generated by Gr-Bat and VC electrodes. This study also revealed that for potentials set at -600 and $-700 \mathrm{mV} \mathrm{VS} \mathrm{Ag/AgCl} \mathrm{for} \mathrm{Gr-Bat} \mathrm{and} \mathrm{VC} \mathrm{respectively,} \mathrm{the} \mathrm{amount}$ of $\mathrm{H}_{2} \mathrm{O}_{2}$ generated in both cases was not significantly influenced by the electrolyte concentration. For $\mathrm{Na}_{2} \mathrm{SO}_{4}$ concentration set at $3 \mathrm{~g} \mathrm{~L}^{-1}$ using same previous potentials, it had been observed that acidic medium $(\mathrm{pH}=3)$ was more favorable for $\mathrm{H}_{2} \mathrm{O}_{2}$ generation in both electrode materials. However, $\mathrm{O}_{2}$ sparging had more influence on $\mathrm{H}_{2} \mathrm{O}_{2}$ production when vitreous carbon electrode was used. 
Later on, the degradation of crystal violet solution by electro-Fenton process had been performed using these two electrodes. Results showed that the Gr-Bat cathode presents the best removal performance than $\mathrm{VC}$ cathode. For a treatment time of $120 \mathrm{~min}$, the removal rates of the crystal violet were 73.18 and $62.27 \%$ for Gr-Bat and VC respectively. This study has demonstrated the possibility of recycling the graphite contained in exhausted batteries and valorizes it as a cathodic material in the electro-Fenton process. Very promising results have been obtained with the use of this low cost material. This innovative approach could help to tackle both issues related to exhausted batteries recycling and water treatment. Thereafter it would be interesting to study the state of the surface of the two electrodes before and after analysis and to follow the evolution of the TOC during electrolysis to see if the compound is mineralizing.

However, in view of studying the lifetime of cathode materials (vitreous carbon versus graphite) different characterization techniques should be carried out to evaluate the physicochemical (X-XPS spectroscopy) and morphological (SEM microscopy) properties of the surface of the electrodes (vitreous carbon versus graphite) before and after treatment of dye solution.

\section{Conflict of interest}

There are no conflicts of interest to declare.

\section{Acknowledgments}

This work was supported by the laboratory of electrochemistry and membrane processes of the polytechnic graduate school of Dakar University, Cheikh Anta Diop. 


\section{References}

[1] Brillas E, Mur E, Sauleda R, Sanchez L, Peral J, Domenech X, Casado J. Aniline mineralization by AOP's: anodic oxidation, photocatalysis, electro-Fenton and photoFenton processes. Appl. Catal. B: Environ, 1998; 16: 31-42.

[2] Oturan MA, Peirotenn J, Pascal C, Aurel A J. Complete destruction of p-nitrophenol in aqueous medium by electro-Fenton method. Environ. Sci. Technol, 2000; 34: 34743479.

[3] Bounab L, Iglesias, Pazos M, Sanroman MÁ, Gonzalez-Romero E. Effective monitoring of the electro-Fenton degradation of phenolic derivatives by differential pulse voltammetry on multi-walled-carbon nanotubes modified screen-printed carbon electrodes. Appl. Catal. B: Environ, 2016; 180: 544-550.

[4] Meijide J, Rodríguez S, Sanromán M A, Pazos M. Comprehensive solution for acetamiprid degradation: Combined electro-Fenton and adsorption process. J Electroanal Chem, 2018; 808: 446-454.

[5] Ioannou LA, Michael C, Vakondios N, Drosou K, Xekoukoulotakis NP, Diamadopoulos E, Fatta-Kassinos D. Winery wastewater purification by reverse osmosis and oxidation of the concentrate by solar photo-Fenton. Sep. Purif. technol, 2013; 118: 659-669.

[6] Bocos E, Pazos M, Sanroman MÁ. electro-Fenton decolourization of dyes in batch mode by the use of catalytic activity of iron loaded hydrogels. J. Chem. Technol Biotechnol. 2014; $89: 1235-1242$.

[7] Oturan MA, Oturan N, Edelahia MC, Podvorica FI, Kacemi KE. Oxidative degradation of herbicide diuron in aqueous medium by Fenton's reaction based advanced oxidation processes. Chem. Eng. J. 2011; 171: 127-135.

[8] Sopaj F, Oturan N, J Pinson, Podvorica FI, Oturan MA. Effect of the anode materials on the efficiency of the electro-Fenton process for the mineralization of the antibiotic sulfamethazine. Appl. Catal. B: Environ. 2016; 199: 331-341.

[9] Yi W, Yuhui L, Tianfu L, Shuqin S, Xuchun G, Hong L, Panagiotis T. Dimethyl phthalate degradation at novel and efficient electro-Fenton cathode. Appl. Catal. B: Environ. 2014; 156-157: 1-7.

[10] Trellu C, Péchaud Y, Oturan N, Mousset E, Huguenot D, van Hullebusch ED, Esposito G, Oturan MA. Comparative study on the removal of humic acids from drinking 
water by anodic oxidation and electro-Fenton processes: Mineralization efficiency and modelling. Appl. Catal. B: Environ. 2016; 194: 32-41,.

[11] Matsue T, Fujihira M, Osa T. Oxidation of alkylbenzenes by electrogenerated hydroxyl radical. J. Electrochem Soc. 1981; 128: 2565-2569.

[12] Brillas E, Sirés I, Oturan M. Electro-Fenton process and related electrochemical technologies based on Fenton's reaction chemistry. Chem Rev. 2009; 109: 6570-6631.

[13] Mousset E, Wang Z, Hammaker J, Lefebvre. O. Physico-chemical properties of pristine graphene and its performance as electrode material for electro-Fenton treatment of wastewater. Electrochim Acta. 2016; 214: 217-230.

[14] Soltani RDC, Rezaee A, Khataee AR, Godini H. Electrochemical generation of hydrogen peroxide using carbon black-, carbon nanotube-, and carbon black/carbon nanotube-coated gas-diffusion cathodes: effect of operational parameters and decolorization study. Res. Chem. Intermed. 2013; 39: 4277-4286.

[15] Lan H, He W, Wang A, Liu R, Liu H, Qu J, Huang CP. An activated carbon fiber cathode for the degradation of glyphosate in aqueous solutions by the electro-Fenton mode: Optimal operational conditions and the deposition of iron on cathode on electrode reusality. Water Res. 2016; 105: 575-582.

[16] Sudoh M, Kodera T, Sakai K, Zhang J Q, Koide K. Oxidative degradation of aqueous phenol effluent with electrogenerated Fenton's Reagent. J Chem Eng Japan. 1986; 19: $513-518$.

[17] Qiang Z, Chang J-H, Huang C-P. Electrochemical generation of hydrogen peroxide from dissolved oxygen in acidic solutions. Water Res. 2002; 36: 85-94.

[18] Zhao. H, Chen Y, Peng Q, Wang Q, Zhao G. Catalytic activity of $\mathrm{MOF}(2 \mathrm{Fe} / \mathrm{Co}) /$ carbon aerogel for improving $\mathrm{H} 2 \mathrm{O} 2$ and $\bullet \mathrm{OH}$ generation in solar photoelectro-Fenton process. Appl. Catal. B: Environ. 2017; 203: 127-137.

[19] Martinez-Huitle CA, Brillas E. Decontamination of wastewaters containing synthetic organic dyes by electrochemical methods: a general review. Appl. Catal. B: Environ. 2009; 87: 105-145.

[20] Xu A, Han W, Li. J, Sun X, Shen J, Wang L. Electrogeneration of hydrogen peroxide using Ti/IrO2-Ta2O5 anode in dual tubular membranes Electro-Fenton reactor for the degradation of tricyclazole without aeration. Chem. Eng. J. 2016; 295: 152-159.

[21] García-Rodríguez O, Bañuelos J A, Zavala A R, Godínez L A. and RodríguezValadez F J. Electrocatalytic Activity of Three Carbon Materials for the In-situ Production 
of Hydrogen Peroxide and Its Application to the Electro-Fenton Heterogeneous Process. Int. J. Chem. React. Eng. 2016, 14 (4).

[22] Zhou L, Hu. Z, Zhang C, Bi Z, Jin T, Zhou M. Electrogeneration of hydrogen peroxide for electro-Fenton system by oxygen reduction using hemically modified graphite felt cathode. Sep. Purif. Technol. 2013; 111: 131-136.

[23] Zhou L, Zhou M, Zhang C, Jiang Y, Bi Z, Yang J. Electro-Fenton degradation of pnitrophenol using the anodized graphite felts. Chem. Eng. J. Chemical Engineering Journal. 2013; 233: 185-192.

[24] Azri MY., Contribution à l'étude de l'incinération des polluants organiques par le procédé d'électrooxydation directe et indirecte sur électrodes modifiées, Thèse UNIVERSITE DES SCIENCES ET DE LA TECHNOLOGIE d'ORAN Mohamed Boudiaf, 2015.

[25] Torres-Palma RA, Sarria V, Torres W, Peringer P, Pulgarin C. Electrochemical treatment of industrial wastewater containing 5-amino-6-methyl-2- benzimidazolone: toward an electrochemical-biological coupling. Water Res. 2003; 37: 3118-3124.

[26] Zaviska F, Drogui P, Blais J-F, Mercier G. In situ active chlorine generation for the treatment of dye-containing effluents. J Appl Electrochem. 2009; 39: 2397-2408.

[27] Azri M, Zerouali D. Traitement d'effluents pétrochimiques par procédés ElectroFenton Etude électrochimique sur la réaction de réduction d'oxygène pour la génération du peroxyde d'hydrogène. Rev. Energ. Renew. 2013; 16: 11-22.

[28] Kuang F, Zhang D, Li Y, Wan Y, Hou B. Electrochemical impedance spectroscopy analysis for oxygen reduction reaction in $3.5 \% \mathrm{NaCl}$ solution. J. Solid. State. Electrochem. 2009; 13:385-390.

[29] AZRI MY, ZEROUALI D. Electrochemical incineration of refractory organic pollution by electrochemically generated fenton's reagent. J. Chil. Chem. Soc. 2012; 57: 1388-1393.

[30] Petrucci E, Da Pozzo A, Di Palma L. On the ability to electrogenerate hydrogen peroxide and to regenerate ferrous ions of three selected carbon-based cathodes for electro-Fenton processes. Chem. Eng. J. 2016; 283: 750-758.

[31] Liu H, Wang C, Xuan X, Jiang C, Cui H. A novel electro-Fenton process for water treatment: reaction-controlled $\mathrm{pH}$ adjustment and performance assessment. Environ Sci Technol. 2007; 41: 2937-2942. 
[32] Hsiao YL, Nobe K. Oxidative reactions of phenol and chlorobenzene with in situ electrogenerated Fentons reagent. Chem Eng Commun. 1993; 126: 97-110.

[33] Yu F, Zhou M,Yu X. Cost-effective electro-Fenton using modified graphite felt that dramatically enhanced on $\mathrm{H} 2 \mathrm{O} 2$ electro-generation without external aeration. Electrochim Acta. 2015; 163: 182-189.

[34] Petrucci E, Di Palma L, Lavecchia R, Zuorro A. Treatment of diazo dye Reactive Green 19 by anodic oxidation on a boron-doped diamond electrode. J. Ind Eng Chem. 2015; 26: 116-121. 


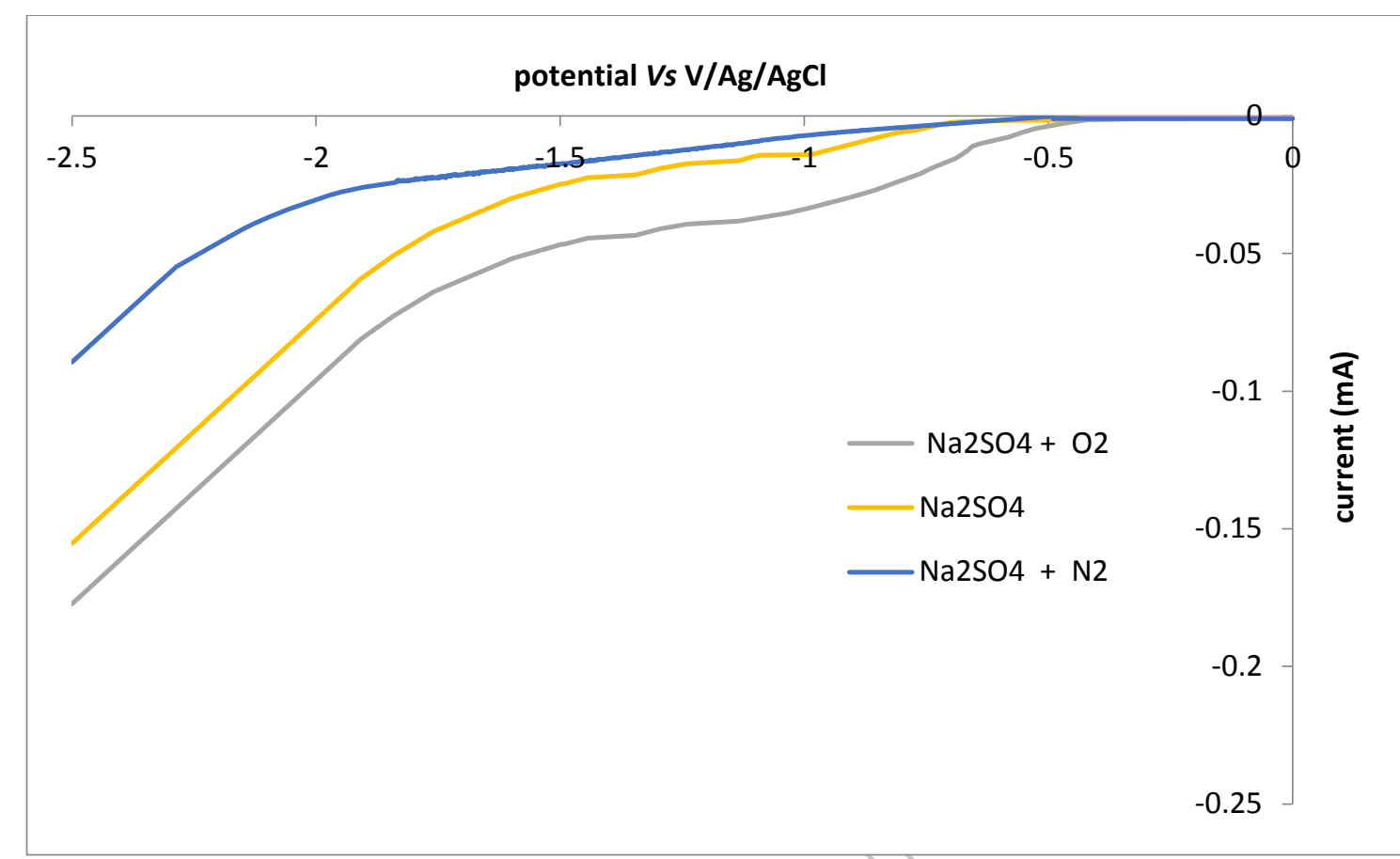

Fig 1 A)

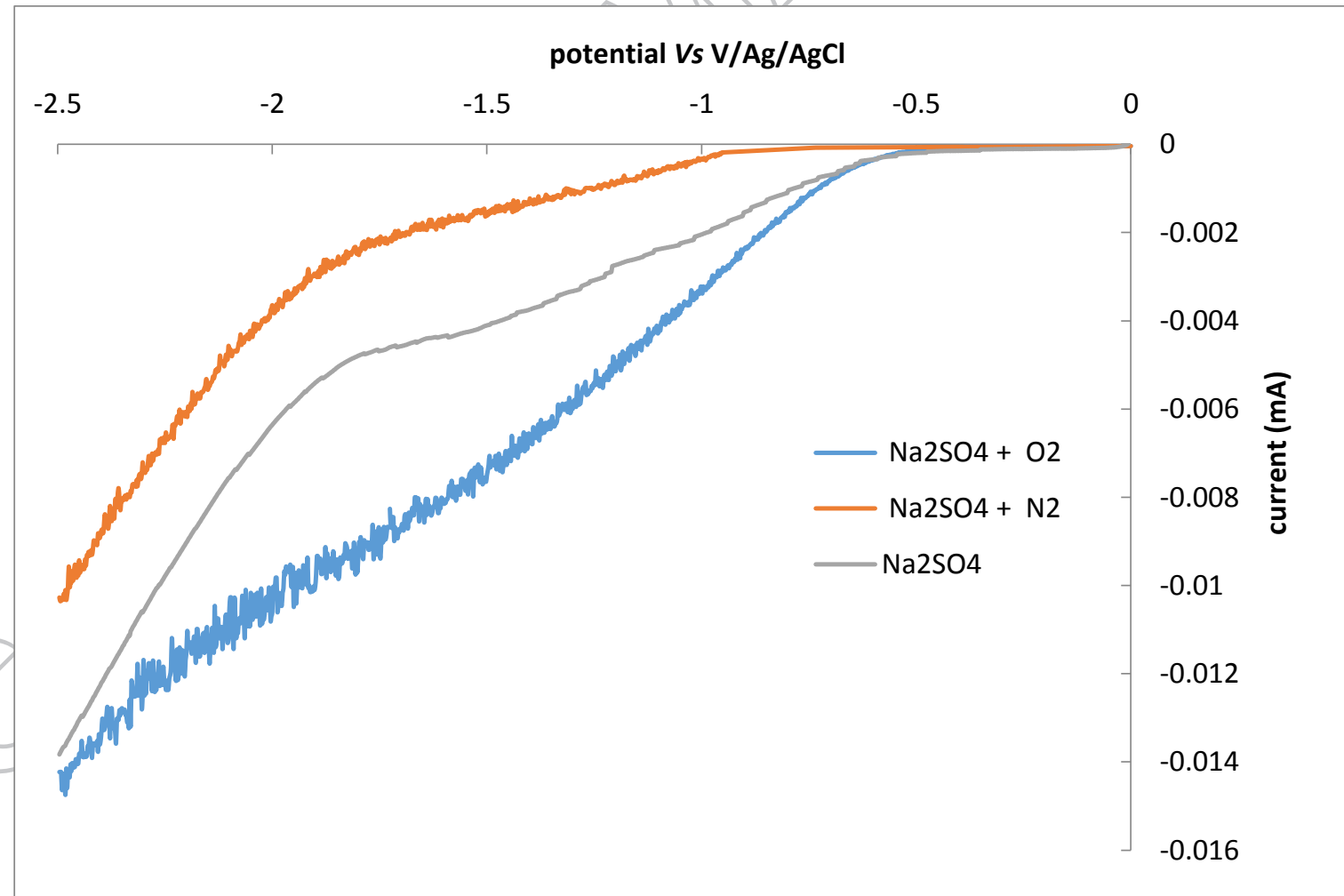

Fig 1 B) 


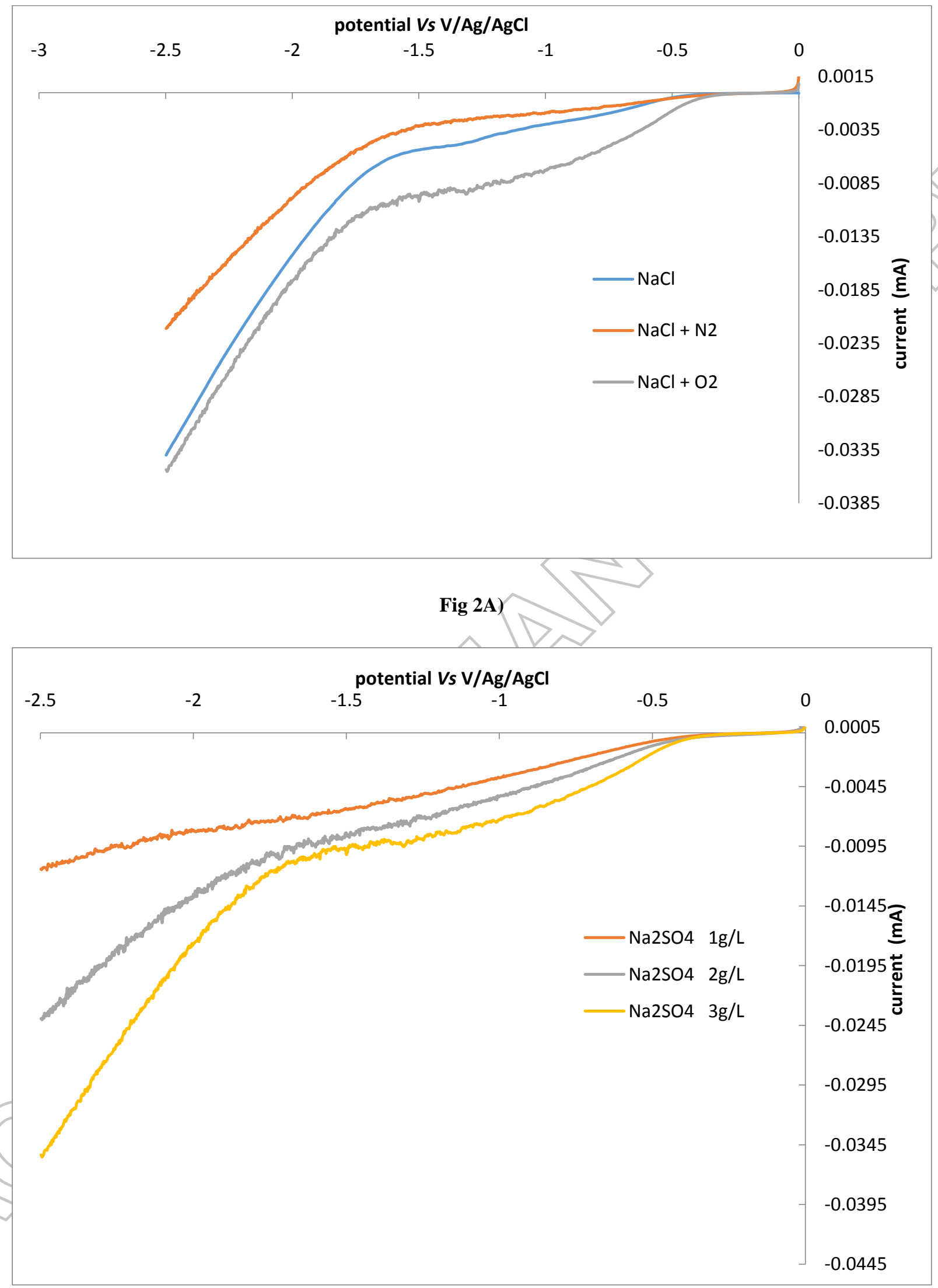

Fig 2B) 


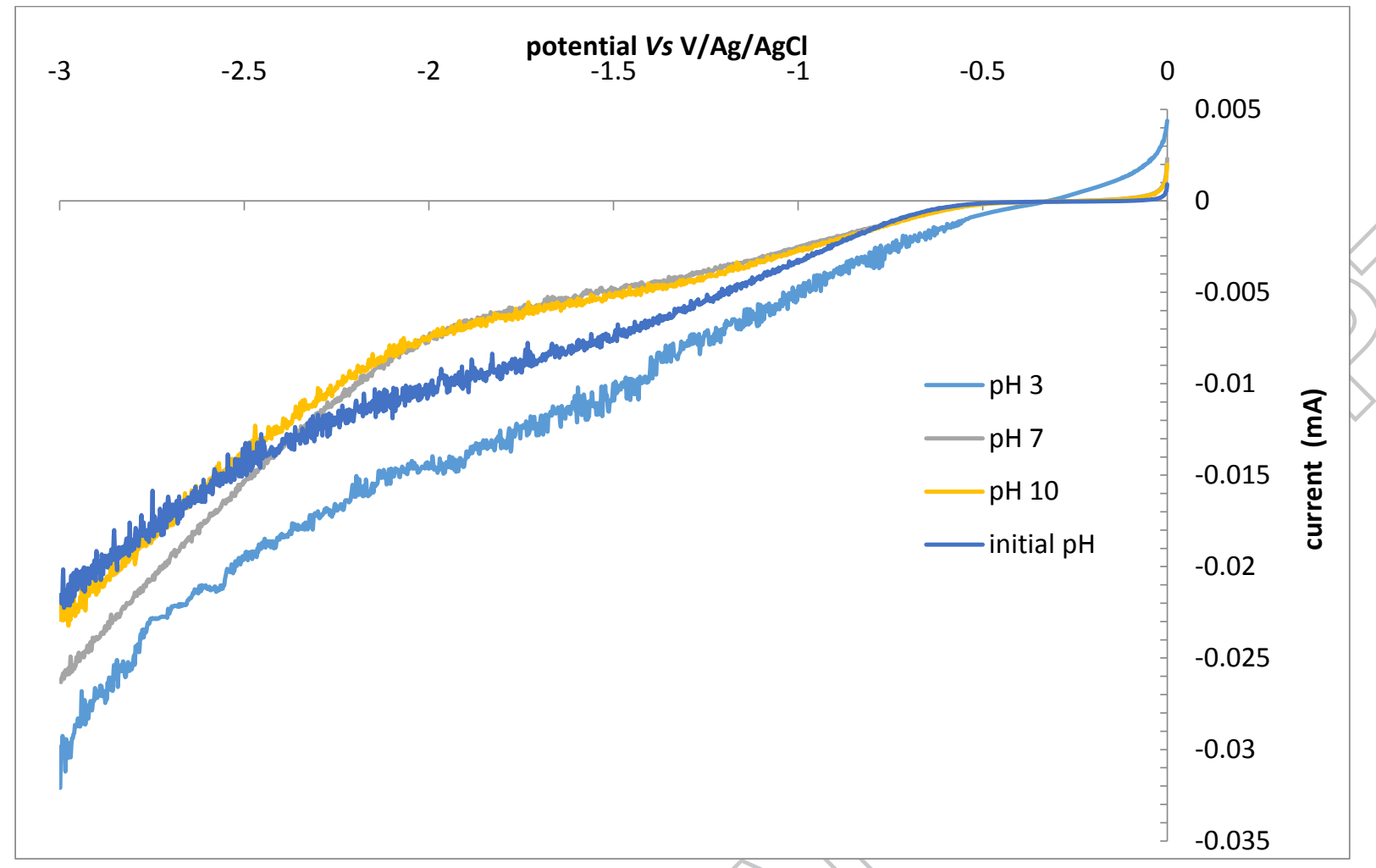

Fig 3A)

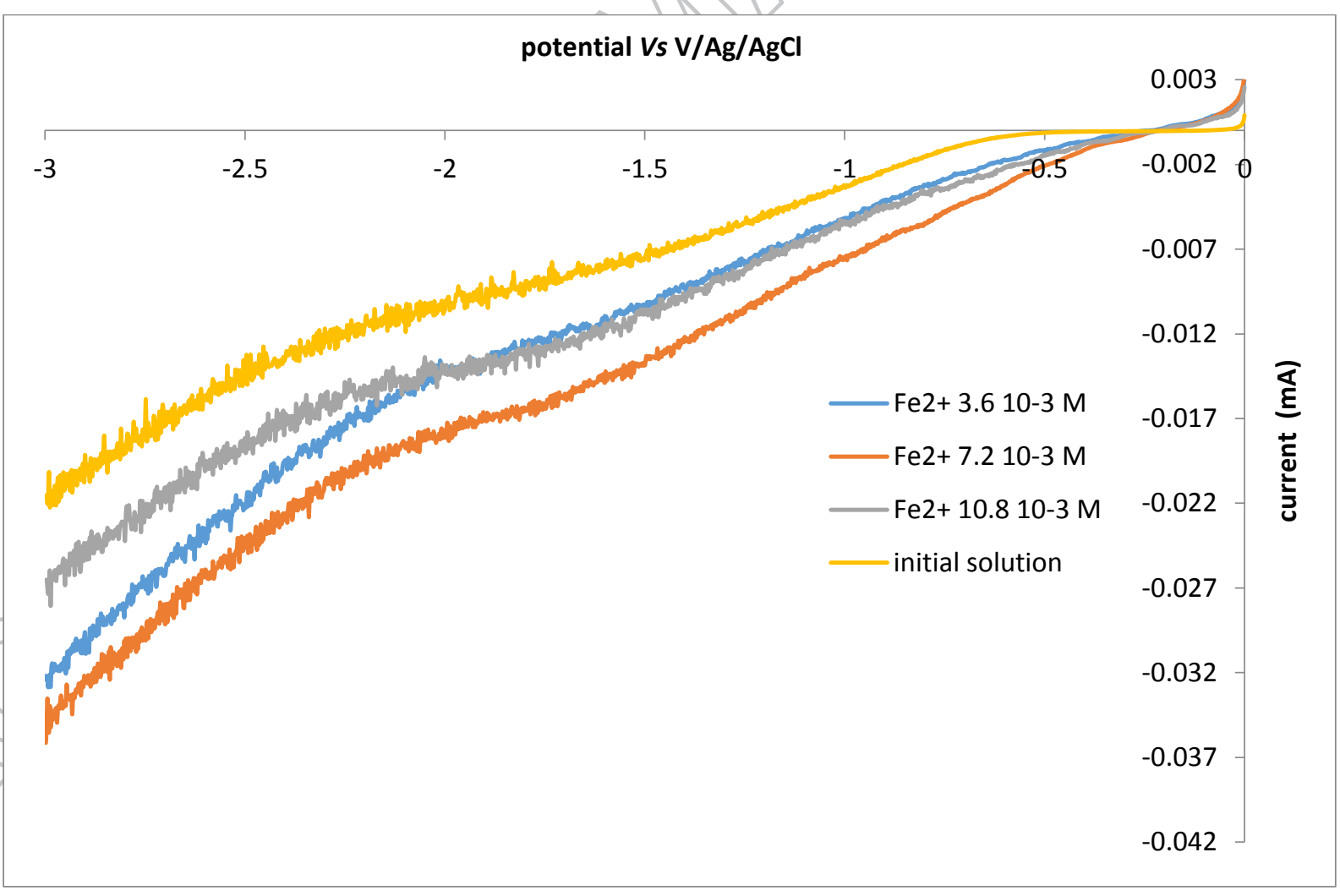

Fig 3B) 


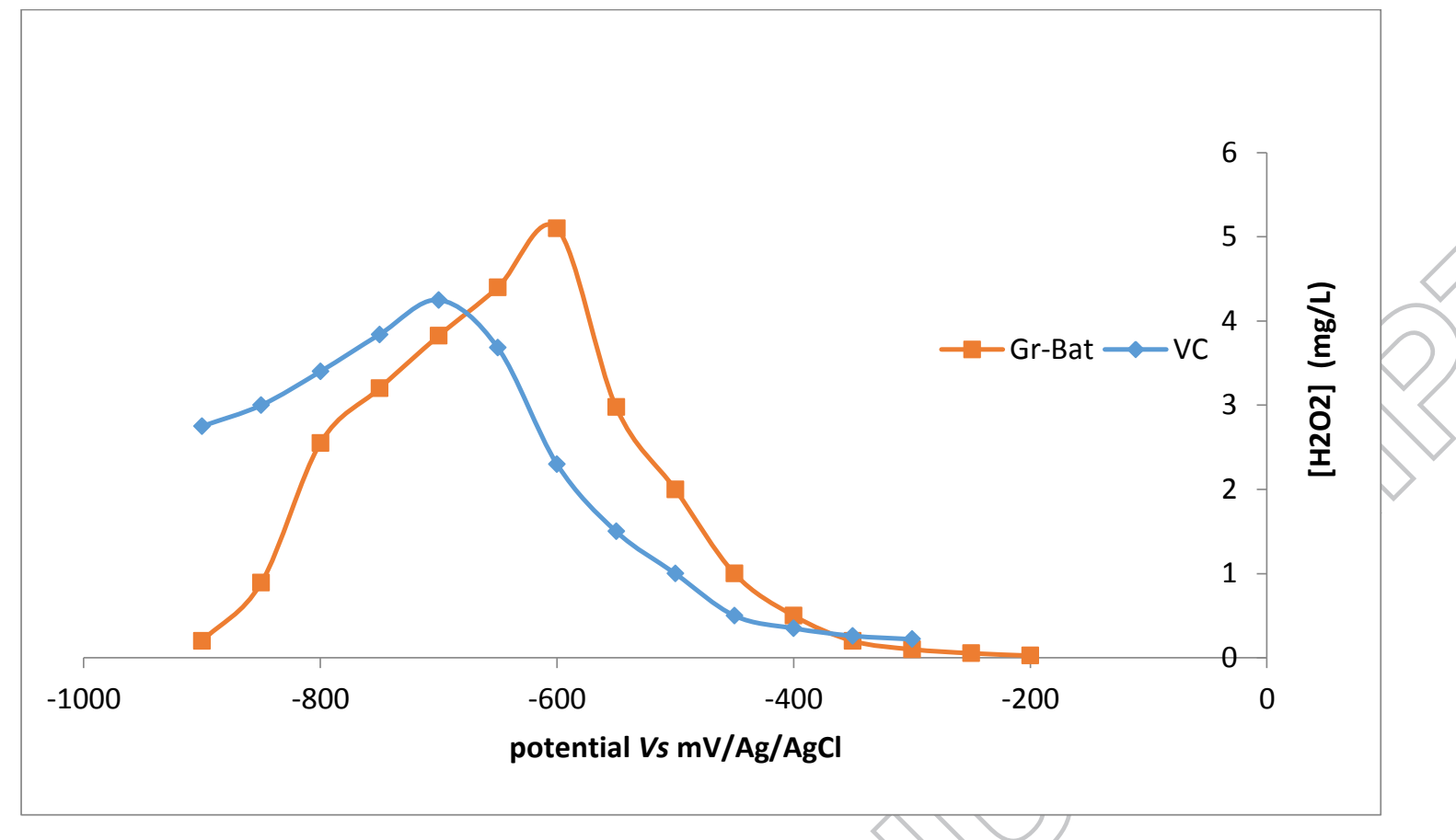

Fig 4A)

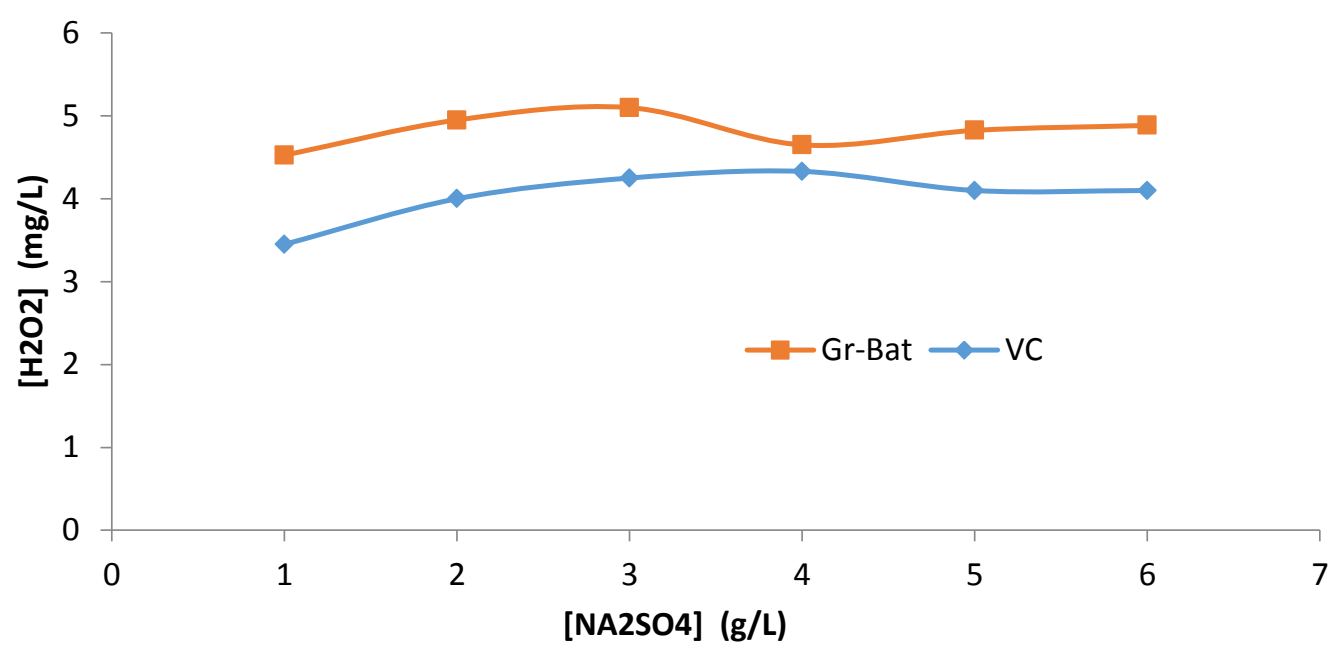

Fig 4B) 


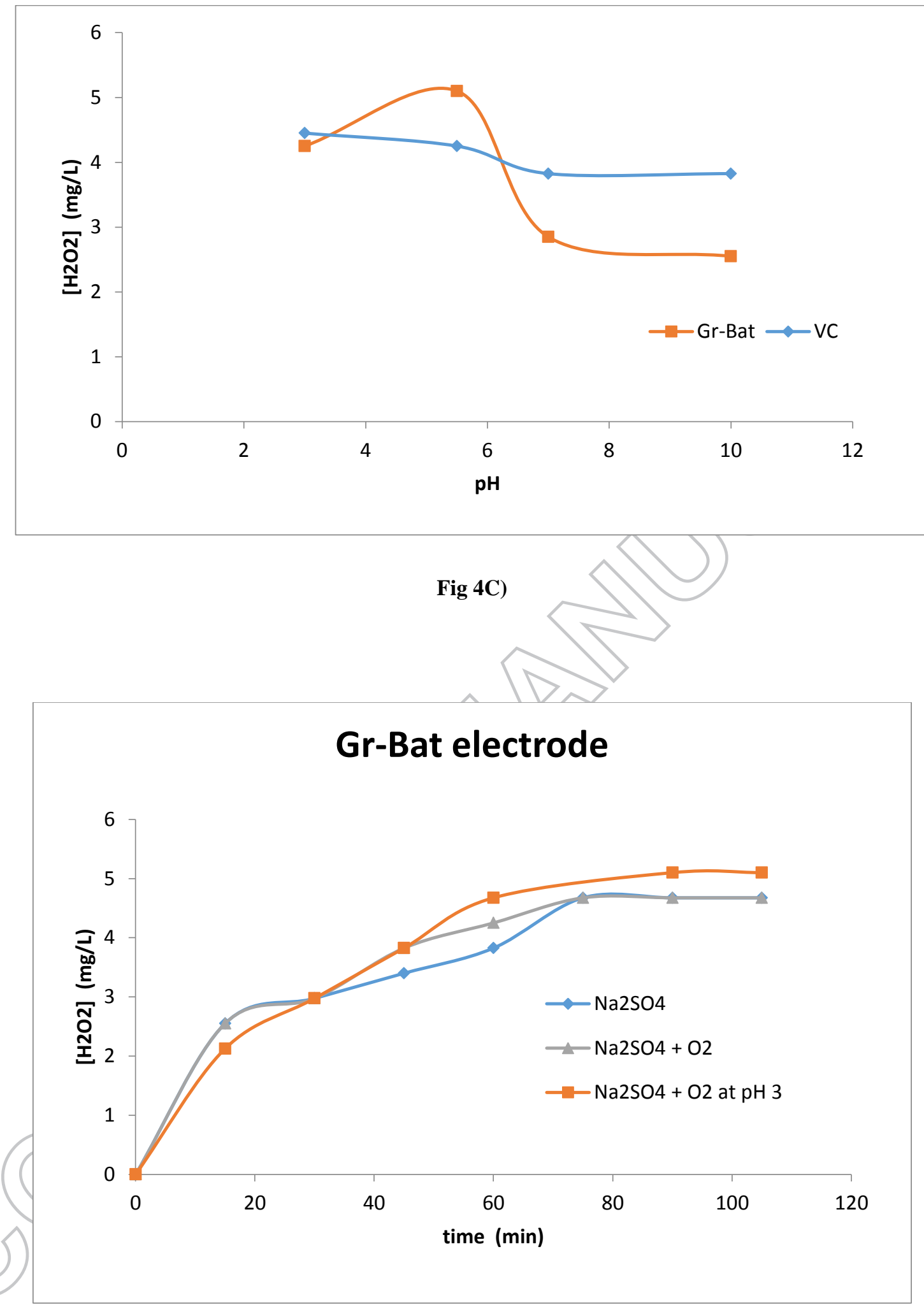

Fig 5A) 


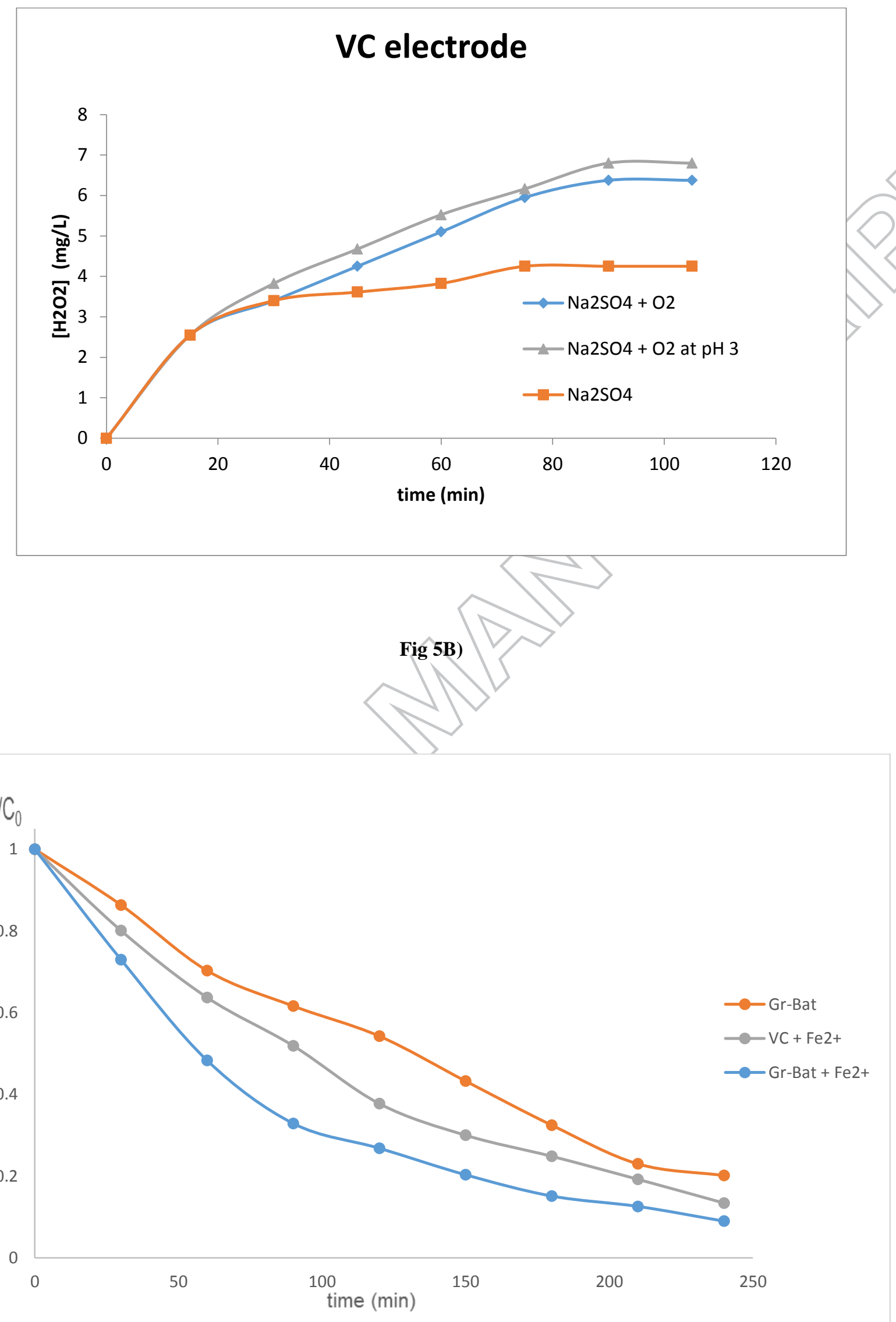




\section{Figure 6}

\section{Figure captions}

Figure 1. Cathodic polarization curves of oxygen reduction for three experimental conditions a) $\left[\mathrm{Na}_{2} \mathrm{SO}_{4}\right]=3 \mathrm{~g} \mathrm{~L}^{-1}$; b) $\left[\mathrm{Na}_{2} \mathrm{SO}_{4}\right]=3 \mathrm{~g} \mathrm{~L}^{-1}+\mathrm{O}_{2} ;$ c) $\left[\mathrm{Na}_{2} \mathrm{SO}_{4}\right]=3 \mathrm{~g} \mathrm{~L}^{-1}+\mathrm{N}_{2} ; \mathrm{v}=10 \mathrm{mV} \mathrm{s}^{-1}$ A) on Gr-Bat electrode B) on VC electrode

Figure 2: Cathodic polarization curves of oxygen reduction on Gr-Bat electrode. A) For three experimental conditions a) $[\mathrm{NaCl}]=3 \mathrm{~g} \mathrm{~L}^{-1}$; b) $[\mathrm{NaCl}]=3 \mathrm{~g} \mathrm{~L}^{-1}+\mathrm{O}_{2}$; c) $[\mathrm{NaCl}]=3 \mathrm{~g} \mathrm{~L}^{-1}+$ $\mathrm{N}_{2} ; \mathrm{v}=10 \mathrm{mV} \mathrm{s}^{-1}$ B) Electrolyte concentration effect on oxygen reduction. Conditions: $\mathrm{O}_{2}$ sparging, $\left[\mathrm{Na}_{2} \mathrm{SO}_{4}\right]=1,2$ and $3 \mathrm{~g} \mathrm{~L}^{-1} ; \mathrm{v}=10 \mathrm{mV} \mathrm{s}^{-1}$

Figure 3: Effect of parameters on oxygen reduction using Gr-Bat electrode A) Effect of $\mathrm{pH}$. Conditions: $\left[\mathrm{Na}_{2} \mathrm{SO}_{4}\right]=3 \mathrm{~g} \mathrm{~L}^{-1} ; \mathrm{O}_{2}$ sparging for different $\mathrm{pH}(3,5.4,7$, and 10$) ; \mathrm{v}=10 \mathrm{mV} \mathrm{s}$ -

${ }^{1}$ B) Effect of $\mathrm{Fe}^{2+}$ concentration. Conditions: $\mathrm{Na}_{2} \mathrm{SO}_{4}$ de $3 \mathrm{~g} \mathrm{~L}^{-1} ;\left[\mathrm{Fe}^{2+}\right]=\left(0 ; 3.6 \times 10^{-3}\right.$; $7.2 \times 10^{-3}$ and $\left.10.8 \times 10^{-3} \mathrm{M}\right) ; \mathrm{v}=10 \mathrm{mV} \mathrm{s}^{-1}$

Figure 4: Effect of parameters on the amount of electro-generated $\mathrm{H}_{2} \mathrm{O}_{2}$; electrolysis time = 90 min. A) Effect of cathodic potential. Conditions: $3 \mathrm{~g} \mathrm{~L}^{-1}$ of $\mathrm{Na}_{2} \mathrm{SO}_{4}$. B) Effect of the electrolyte concentration $\left(\mathrm{Na}_{2} \mathrm{SO}_{4}\right)$. Conditions: Gr-Bat potential $=-600 \mathrm{mV}$; VC potential $=-$ $700 \mathrm{mV}$. C) Effect of different $\mathrm{pH}$ values (3, initial solution (5.4), 7 and, 10). Conditions: $\left[\mathrm{Na}_{2} \mathrm{SO}_{4}\right]=3 \mathrm{~g} \mathrm{~L}^{-1} ;$ Gr-Bat potential $=-600 \mathrm{mV} ; \mathrm{VC}$ potential $=-700 \mathrm{mV}$.

Figure 5: Effect of $\mathrm{O}_{2}$ bubbling on the production of $\mathrm{H}_{2} \mathrm{O}_{2}$. Conditions: $\left[\mathrm{Na}_{2} \mathrm{SO}_{4}\right]=3 \mathrm{~g} \mathrm{~L}^{-1}$ with and without $\mathrm{pH}$ adjustment to 3. A) on Gr-Bat electrode; Voltage $=-600 \mathrm{mV} V_{S}$ $\mathrm{Ag} / \mathrm{AgCl}$ B) on VC electrode; Voltage $=-700 \mathrm{mV} V_{S} \mathrm{Ag} / \mathrm{AgCl}$.

Figure 6: Evolution of crystal violet concentration as a function of electrolysis time. Conditions: $\mathrm{pH}=3 ;\left[\mathrm{Na}_{2} \mathrm{SO}_{4}\right]=5.10^{-2} \mathrm{M} ;\left[\mathrm{Fe}^{2+}\right]=10^{-4} \mathrm{M} ; \mathrm{I}=300 \mathrm{~mA}$. 